may be tested in practice. Using the Waltz's analysis' levels concept Wawrzyński has described myth-based processes and the social distribution of knowledge during the war. Even if sometimes interpretative methodologies have been criticized as speculative, Wawrzyński's one deserves to be considered by political scientists.

Crucial meaning for the importance of reviewed work has an extension of bibliographical sources; Wawrzyński has decided to refer to cultural anthropology, philosophy of culture and sociology and adapted other discipline's and achievements into political science. Probably, he is one of the few that has attempted to interpret Cassirer's, Eliade's, Kołakowski's, Malinowski’s, Levi-Strauss' or Wojciech
Burszta’s and Antonina Kłoskowska’s concepts to satisfy the research needs of political science. And itself it is praiseworthy. But it is even more commendable, because his intellectual ordeal yields satisfying and inspiring results.

Summing up, the Patryk Wawrzyński's book merits recommendation; in short it can be described as instructive, interesting, and a well-written monograph from the borderland of sciences. Even if the first chapter seems to be too much a review of different concepts and definitions, it is still a valuable theoretical introduction to subsequent studies. Time spent on the lecture of this book will not be lost, quite the contrary it will be a good choice, both for academics and students.

\title{
A book review: \\ Luciano Canfora, Andrea Giardina, Chiara Frugoni, Alessandro Barbero, Alberto Mario Banti, Emilio Gentile, Andrea Graziosi, Vittorio Vidotto, Giovanni Sabbatucci, Andrea Riccardi, Michelle Perrot, I Volti Del Potere, Roma-Bari: Editori Laterza, 2010, pp. 318
}

by Agnieszka Latosińska

The book I Volti Del Potere (Eng. The Faces of Power) is a collective work consisting of eleven chapters. The authors in an interesting way present the political fates and changes made by the great heroes of history, as well as the pros and cons of their governments, the stigma of which is often felt to this day.
In the opinion of the author of the reviewed book, the most interesting is chapter VI dedicated to Benito Mussolini and Fascism.

There is a complicated complexity in the relationship between Mussolini and Fascism. These relations started a new system of governance in Italy after 1922. 
To characterize them, you must follow the victory in the political biography of Mussolini and also the history of fascism in the years prior to their rise to power.

The origins of Fascism reaches back to March 23, 1919 when Benito Mussolini established Fascia di combattimento (Eng. Leagues of Combat), originally numbering about fifty members. At the end of 1919, the number of people reached 800 throughout Italy. After defeat in the November elections that same year, Mussolini was close to leaving politics. Ultimately he continued to engage in political activities aimed at his ascent to power.

At the end of 1921 Mussolini made himself known to the public as II Duce, standing as the head of his created Italian Fascist Party, resulting from the conversion of the Leagues of Combat with around 150,000 members.

The fast success that fascism achieved after 1920 and its transformation into a mass movement was not only due to the initiative and capabilities of Mussolini. Fascism but owes its success to the violence and brutality of armed militias whose activity was led by local leaders, most of them very young, enjoying the prestige and personal authority among the fascist masses in their provinces.

A year later on October 29, 1922 Mussolini received the task of forming a new government from King Victor Emmanuel III. This was undoubtedly Mussolini's personal success. At the age of 39 he became the Prime Minister of the Italian Government.
Most anti-fascist activists didn't realize the real power of fascism. Not many people were fully aware of the threat fascism posed to parliamentary democracy and to Italians themselves. The extremely short period of time that elapsed since the creation of the National Fascist Party to their takeover of power was the factor that allows us to understand why part of the conservative supporters of fascism and anti-fascists did not recognize the true nature of fascism. This short period of time also allows us to understand Mussolini's motives in setting up the one-party system.

Mussolini's government was officially sanctioned by the Constitution, as confirmed through a vote of confidence by parliament, although it must be clearly stated that the method Mussolini used to come to power was not a parliamentary method, but rather revolutionary.

In reality, Mussolini's assignment to create the government was not the spontaneous and autonomous decision of King Victor Emmanuel III. The king was forced to do so, under the threat of using force by the Fascists and their armed militias - the fascists, had only about thirty members in Parliament.

The revolutionary and novel way that Mussolini came to power was based on the fact that never before had any parliamentary country had as its Prime Minister the leader of armed bands, organized into a party, who publicly declared that the age of democracy was finished, that the liberal state had ceased to exist and that parliamentarism as such is dead. 
Around this same time the liberal, antifascist Giovanni Amendola used the term totalitarian for the first time to describe fascist methods. This became a popular term in the vocabulary of anti-fascists in Italy. It was also used by one of the greatest Catholic anti-fascist activists, Father Luigi Sturzo, forced by Mussolini's regime to resign from leading the Italian People's Party and leave the country.

Shortly afterwards, another Catholic anti-fascist activist from the opposition, Igino Giordani, warned the Church not to succumb to flattery of the fascist government, revealing the impossibility to reconcile the Catholic religion with the "fascist religion," as he called the political concept of fascism. Fascism, with its "totalitarian spirit, violence, amorality, lack of legality and oppression" only sought to use the Catholic Church as an instrument to support the realization of Fascist political domination.

In the 1930's fascism consistently strived to transform the Italian monarchy of that time into a new, totalitarian, fascist state. The Grand Council of Fascism in 1929 was transformed into the highest constitutional authority in the country, depriving the monarchy automatic succession to the throne. It abolished the Chamber of Deputies, the last parliamentary state authority and created in its place the Chamber of Fasci and Corporations.

Together with the development of totalitarian methods of the government by Mussolini and his militia, fascism dominated the Italian political scene for a period of about twenty years.

Mussolini was the first dictator of the twentieth century revered by the masses. In Italy his strong personality cult developed as a charismatic leader, capable of assuring the country a strong position in the international arena.

The apotheosis of Mussolini as a living god and his cult was devoted to the main aspect of fascism as a political religion, along with acknowledgment of the fascist states "sanctity". It was this "holy" state that was condemned by Pope Pius XI, who described it as "statolatria Pagana" (a pagan cult of the state). This was a constant topic of tensions and conflict between the regime and the Vatican, despite the signing of the Concordat in 1929.

In Europe in the 1920's there was no such living cult leader. Even in Bolshevik Russia, Lenin's cult did not develop until after his death.

The first person who noticed the similarities in fascism and Bolshevism, combining them by using the term totalitarianism was Father Luigi Sturzo in 1926. He was one of the first anti-fascists forced to leave Italy and go into exile by Mussolini’s regime.

In reality it was not a Bolshevik totalitarian model. A fascist totalitarian model had already existed and successfully spread in Europe between the wars, between new dictators: in Bolshevik Russia, on the Iberian Peninsula, in Eastern Europe, to finally erupt in Germany with the Nazi rise to power in the early 1930's. 